\title{
Effects of Gultural Conditions on Nitrate Reductase in Photobacterium sepia
}

\author{
By D. J. D. NICHOLAS, * W. J. REDMOND AND M. A. WRIGHT \\ Chemical Microbiology Department, Long Ashton Research Station, \\ University of Bristol
}

(Received 11 November 1963)

\begin{abstract}
SUMMARY
The effect of cultural conditions on the growth and nitrate reductase activity of a bacterium, now identified as Photobacterium sepia, were examined. The bacterium grew well with ammonium chloride, ammonium nitrate or potassium nitrate as sole nitrogen source. Nitrate reductase activity was markedly decreased in organisms deficient in molybdenum or iron and in organisms grown at high oxygen pressures. The $\boldsymbol{P}$. sepia enzyme is thus similar to nitrate reductases from other bacteria. The $P$. sepia enzyme is constitutive; it is present in organisms grown with ammonium chloride in the absence of nitrate; the ammonium radical did not depress enzyme activity. Under certain conditions $\left(\mathrm{NH}_{4} \mathrm{NO}_{3}\right.$ medium, $10 \%, \mathrm{v} / \mathrm{v}$, $\mathrm{O}_{2}$ in $\mathrm{N}_{2}$ ) molybdenum (10 $\mu \mathrm{g}$./1.) depressed the nitrate reductase activity, but this effect was annulled by repeated subcultivation in molybdenumdeficient medium. Vanadium and especially tungsten, also inhibited the enzyme. The uptake of nitric oxide was decreased in organisms depleted of iron but was increased in organisms deficient in molybdenum. The behaviour of nitrate reductase preparations during fractionation whether from $P$. sepia grown with $\mathrm{KNO}_{3}$ or with $\mathrm{NH}_{4} \mathrm{Cl}$ suggests that the enzyme is the same from both sources.
\end{abstract}

\section{INTRODUCTION}

There are two types of microbial enzymes which reduce nitrate to nitrite. The assimilatory enzyme contains flavin and molybdenum and usually utilizes reduced

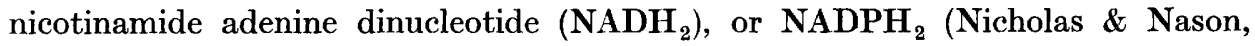
1954) as a hydrogen donor, whereas the dissimilatory one has an additional iron requirement (Verhoeven, 1952; Sato, 1956; Fewson \& Nicholas, 1961; Nicholas, 1963). During assimilation, nitrate is incorporated into cell nitrogen, whereas in the dissimilatory process or 'nitrate respiration' nitrate serves as an alternative hydrogen acceptor to oxygen.

A nitrate reductase characterized in Achromobacter fischeri by Sadana \& McElroy (1957) was shown to be induced by its substrate only. They claimed that organisms deficient in iron had decreased enzyme activity but that a deficiency of other micronutrients, including molybdenum, was without effect. Lindeberg, Lode \& Somme (1963) found that nitrate reductase in Achromobacter species decreased when the oxygen pressure in the medium was increased and in this respect it resembled the

\footnotetext{
* Present address : Biochemistry Department, Waite Institute, University of Adelaide, South Australia.
} 
dissimilatory enzyme from other bacteria. We have re-examined the cultures used by Sadana \& McElroy (1957) and find that the bacterium used by them is in fact Photobacterium sepia which can be readily trained to grow with nitrate as sole nitrogen source. By using reduced benzylviologen as hydrogen donor we have found that the enzyme is dependent on both molybdenum and iron for its activity (Nicholas, Redmond \& Wright, 1963). This enzyme is constitutive since it is present in $P$. sepia grown with ammonium chloride but no nitrate. The effect of oxygen pressure on enzyme production was also examined.

\section{METHODS}

Organism. The bacterium used in these experiments was kindly supplied by Dr W. D. McElroy (McCollum-Pratt Institute, Johns Hopkins University, Baltimore, U.S.A.) as Achromobacter fischeri. However, subsequent biochemical tests by Miss Anne Morrison (National Collection Type Cultures, Torry Research Station, Aberdeen) identified the organism as Photobacterium sepia.

Culture media. The organism was grown on the following basal medium: $\mathrm{NaCl}$, 30 g.; $\mathrm{Na}_{2} \mathrm{HPO}_{4}, 5.5$ g.; $\mathrm{KH}_{2} \mathrm{PO}_{4}, 2 \cdot 1$ g.; $\mathrm{MgSO}_{4} 7 \mathrm{H}_{2} \mathrm{O}, 0 \cdot 2$ g.; $\mathrm{NH}_{4} \mathrm{NO}_{3}, 5$ g.; glycerol, $3 \mathrm{ml}$; $\mathrm{Fe}, 2 \mathrm{mg}$. (as $\mathrm{FeCl}_{3}$ ); $\mathrm{Mo}, \mathbf{0} \cdot 1 \mathrm{mg}$. (as $\left(\mathrm{NH}_{4}\right)_{2} \mathrm{MoO}_{4}$ ); water, $1 \mathrm{l}$. $\mathrm{KNO}_{3}\left(12 \cdot 2 \mathrm{~g}\right.$.) and $\mathrm{NH}_{4} \mathrm{Cl}\left(6 \cdot 5 \mathrm{~g}\right.$.) were substituted for $\mathrm{NH}_{4} \mathrm{NO}_{3}$ in some cultures. Stocks of organism were maintained on nutrient agar slopes of the following composition: $\mathrm{NaCl}, 30 \mathrm{~g}$.; peptone, $5 \mathrm{~g}$.; beef extract, $3 \mathrm{~g}$.; glycerol, $5 \mathrm{ml}$.; $\mathrm{CaCO}_{3}$, 0.1 g.; agar, 10 g.; water 11 . The water was deionized in a Permutit Deminrolit Mark IV plant and distilled once in an all-glass still. The media were sterilized at $115^{\circ}$ for $15 \mathrm{~min}$.

Purification of culture media. Molybdenum was removed by the copper sulphide co-precipitation method (Nicholas, 1952) and iron by the calcium carbonate adsorption technique of Steinberg (1935). The micronutrient elements $\mathrm{Fe}, \mathrm{Mo}, \mathrm{V}$ and $\mathrm{W}$, spectrographically tested for purity, were supplied by Johnson Matthey (Hatton Garden, London, E.C. 1). Culture solutions purified from Mo were adjusted to $\mathrm{pH} 7 \cdot 1$ with $5 \%(\mathrm{w} / \mathrm{v})$ sodium hydroxide which had been passed through a well washed Amberlite (IRA-400) anion-exchange column (24 in. $\times 1$ in.) to remove molybdate. The Mo content of the sodium hydroxide after passage through the resin was $<0.001 \mu \mathrm{g} . / \mathrm{ml}$. as determined by bioassay (Nicholas, 1952). The Fedeficient cultures were adjusted to $\mathrm{pH} 7 \cdot 1$ with redistilled $6 \mathrm{~N}-\mathrm{HCl}$. It was not found necessary to purify the glycerol.

Cultures grown in 1.5 l. Erlenmeyer flasks containing $400 \mathrm{ml}$. medium were shaken continuously on a reciprocator ( 2 in. throw) at 100 strokes/min. Gas mixtures of oxygen in nitrogen, prepared by means of rotameter tubes, were dispersed through the medium by No. 2 porosity glass sinters $(250 \mathrm{ml}$. gas/min./flask). A $3 \%(v / v)$ inoculum grown in the appropriate medium was transferred into the large flasks aseptically and the cultures incubated at $24^{\circ}$ for $18 \mathrm{hr}$.

Collection of organisms. Bacteria were harvested in an M.S.E. refrigerated centrifuge at $6,000 \mathrm{~g}$ at $4^{\circ}$ and washed twice with $3 \% \mathrm{NaCl}$ to remove nitrite.

Preparation of cell-free extracts. The washed bacteria lysed in distilled water $(1 \mathrm{~g}$. wet wt. $/ 10 \mathrm{ml}$.) were centrifuged at $25,400 \mathrm{~g}$ for $20 \mathrm{~min}$. at $4^{\circ}$ as described by Sadana \& McElroy (1957). The sediment was re-extracted with water $(1 \mathrm{~g}$. wet 
wt. $15 \mathrm{ml}$.) and centrifuged as before. Most of the nitrate reductase activity was in the second water extract.

Nitrate reductase. Method 1 . The enzymic reduction of nitrate by whole bacteria was followed anaerobically in Thunberg tubes by using reduced benzylviologen (BVH) as a hydrogen donor. In the side-arm, $\mathbf{0 . 2} \mathrm{ml} . \mathbf{1 0}^{-\mathbf{3}} \mathbf{M}$-benzylviologen (BV), $1 \mathrm{mg}$. palladized asbestos and $0.3 \mathrm{ml} .2 .5 \times 10^{-1} \mathrm{M}$-phosphate buffer ( $\mathrm{pH} \mathrm{7.5}$ ); in the tube $0 \cdot 1 \mathrm{ml} .10^{-1} \mathrm{M}-\mathrm{KNO}_{3}, 0 \cdot 1 \mathrm{ml}$. bacterial suspension (equiv. $2 \mathrm{mg} . \mathrm{N} / \mathrm{ml}$.), $0.3 \mathrm{ml} .2 .5 \times 10^{-1} \mathrm{M}$-phosphate buffer ( $\mathrm{pH} \mathrm{7.5}$ ). The tube was evacuated and flushed with high purity hydrogen passed through a Deoxo-catalytic deoxygenator (Baker Platinum Division, Englehard Industries Ltd., 52 High Holborn Street, London) at which stage the dye was fully reduced. The tubes when finally evacuated were pre-incubated for $5 \mathrm{~min}$. at $30^{\circ}$ before tipping in the reduced dye; the reaction was terminated after a further $10 \mathrm{~min}$. by adding $0.1 \mathrm{ml}$. M-zinc acetate and $1.9 \mathrm{ml}$. $95 \%(\mathrm{v} / \mathrm{v})$ ethanol in water (Medina \& Nicholas, 1957). After centrifuging at $4000 \mathrm{~g}$ for 5 min., nitrite was determined in a sample of the supernatant solution by the sulphanilamide method (Fewson \& Nicholas, 1961).

Method 2. Reduced benzylviologen, prepared by the palladized asbestos-hydrogen method, did not function as a hydrogen donor for nitrate reductase in cell-free extracts. The dye reduced with sodium dithionite was, however, a suitable donor for the extracted enzyme (Sadana \& McElroy, 1957). The specific activity of the enzyme is defined as $\mu \mathrm{m}$-mole $\mathrm{NO}_{\mathbf{2}}{ }^{-}$formed $/ 10 \mathrm{~min} . / \mathrm{mg}$. $/$ bacterial total-N.

Nitric oxide (NO) reductase. The uptake of NO was measured in a Warburg apparatus. The main compartment contained $0.5 \mathrm{ml}$. bacterial suspension (equiv. $2 \mathrm{mg} . \mathrm{N} / \mathrm{ml}$.), $1.5 \mathrm{ml} .0 \cdot 1 \mathrm{M}-\mathrm{phosphate}(\mathrm{pH} \mathrm{7.5})$; the side-arm contained $0 \cdot 2 \mathrm{ml} .10^{-2}$ $\mathrm{M}-\mathrm{NADH}_{2}, 0.1 \mathrm{mg}$. crystalline alcohol dehydrogenase, $0.1 \mathrm{ml} .5 \%(\mathrm{v} / \mathrm{v})$ ethanol in water, and the centre well $0.2 \mathrm{ml} .20 \%(\mathrm{w} / \mathrm{v}) \mathrm{KOH}$. The vessels were flushed with oxygen-free nitrogen for $40 \mathrm{~min}$. and then with approximately $20 \%(\mathrm{v} / \mathrm{v})$ NO in $\mathbf{N}_{2}$ until damp litmus paper turned red when held in the exit gas stream from the side-arm stopper. The apparatus was equilibrated at $30^{\circ}$ for $15 \mathrm{~min}$. and then the $\mathrm{NADH}_{2}$-generating system tipped in to start the reaction. The nitric oxide was prepared by the reaction: $3 \mathrm{Cu}+8 \mathrm{HNO}_{3}=2 \mathrm{NO}+3 \mathrm{Cu}\left(\mathrm{NO}_{3}\right)_{2}+4 \mathrm{H}_{2} \mathrm{O}$. The NO evolved was displaced by a slow stream of oxygen-free nitrogen and after passing through Dreschel bottles containing boiled water the gas mixture was collected over water in a glass aspirator. The NO content of the gas mixture was determined in a gas burette connected to a reservoir containing saturated pyrogallol in $20 \%(\mathrm{w} / \mathrm{v}) \mathrm{KOH}$. The volume of gas was measured and oxygen introduced from a cylinder. After vigorous shaking the contraction in gas volume, due to the reaction $2 \mathrm{NO}+\mathrm{O}_{2} \rightarrow 2 \mathrm{NO}_{2}$, was measured. Nitrogen dioxide in the presence of excess $\mathrm{O}_{2}$ dissolves readily in the alkaline pyrogallol. The gas mixtures prepared in this way contained between 20 and $25 \%(\mathrm{v} / \mathrm{v}) \mathrm{NO}$ in $\mathrm{N}_{2}$. Oxygen must be rigorously removed from the system since it reacts readily with $\mathrm{NO}$ to give $\mathrm{NO}_{2}$ which dissolves in water to give a mixture of nitrous and nitric acids.

Protein and total-nitrogen determinations. Protein was determined by the Folin method (Lowry, Rosebrough, Farr \& Randall, 1951) and the total bacterialnitrogen by micro-Kjeldahl. The ${ }^{15} \mathrm{~N}$ technique used was that described by San Pietro (1957) and Simms \& Cocking (1958). 


\section{RESULTS}

Identity of the organism used. The organism has the following characteristics: single short rods with rounded ends, motile, non-sporing, $2 \mathrm{~mm}$. convex off-white colonies with shiny surface and an entire edge, self-luminous; is Gram-negative, aerobic, insensitive to 'vibriostat' (Vibriostatic compound 0/129; 2,4-diamino-6-7di-isopropyl pteridine; Spencer, 1955 made by Difco Laboratories, Michigan, U.S.A.), liquefies gelatin, produces acid from glucose, sucrose, maltose and mannitol, reduces nitrate to nitrite.

These results suggest that this bacterium, which has been used under the name Achromobacter fischeri by Sadana \& McElroy (1957), is very similar to Photobacterium sepia described by Spencer (1955). The genus Photobacterium is a member of the Pseudomonadaceae and is no longer referred to as Achromobacter (Bergey's Manual, 1957). Since $\boldsymbol{P}$. fischeri is a curved rod sensitive to vibriostat and does not liquefy gelatin, it seems likely that the organism used here is $\boldsymbol{P}$. sepia. Spencer (1955) suggested that $\boldsymbol{P}$. sepia be placed in the genus Aeromonas and $\boldsymbol{P}$. fischeri in the genus Vibrio.

Table 1. Nitrate reductase activity of Photobacterium sepia whole organisms, in relation to the nitrogen source in the growth medium

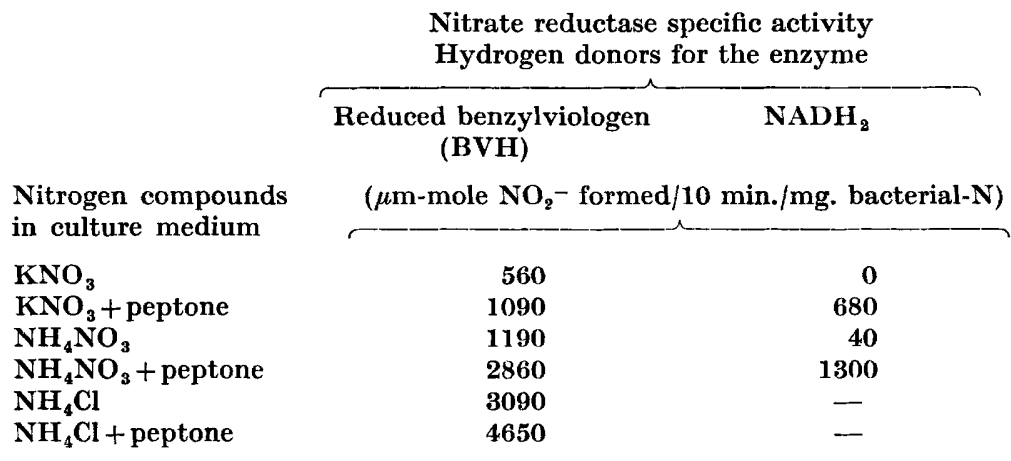

Table 2. The uptake of ${ }^{15} \mathrm{~N}$ by Photobacterium sepia from various forms of nitrogen in relation to molybdenum requirements and nitrate reductase activity of the organisms

Culture solutions A and B were equivalent in total nitrogen.

$\begin{array}{rlrrrr}\text { A } 5 \text { g. } & { }^{15} \mathrm{NH}_{4} \mathrm{NO}_{3}(3 \cdot 05 \text { atom \% excess } \mathrm{N}) & 0 & 2 & 672 & 2 \cdot 35 \\ \text { B } & & 10 & 1020 & 546 & 2 \cdot 71 \\ \mathbf{6 \cdot 3} \text { g. } & \mathrm{K}^{15} \mathrm{NO}_{3}(3 \cdot 08 \text { atom } \% \text { excess } \mathrm{N}) & 0 & 330 & 496 & 0 \cdot 35 \\ & \mathrm{NH}_{4} \mathrm{Cl} & 10 & 820 & 504 & 0 \cdot 32\end{array}$

* $\mu \mathrm{m}$-mole $\mathrm{NO}_{2}-$ formed/10 min./mg. bacterial-N. 


\section{Effect of various factors on nitrate reductase activity}

Nitrogen source. The results in Table 1 show that the nitrate reductase activity was greatest when the ammonium radical was the only nitrogen source. Thus the enzyme is constitutive since it is formed in the absence of its substrate. The inclusion of peptone in the medium not only increased enzyme production but also enhanced its stability in organisms stored at $4^{\circ}$ for $24 \mathrm{hr}$. The results in Table 2 show that molybdenum deficiency restricted nitrate reductase activity in organisms grown with $\mathrm{NH}_{4} \mathrm{NO}_{3}$ or $\mathrm{KNO}_{3} / \mathrm{NH}_{4} \mathrm{Cl}$. The ${ }^{15} \mathrm{~N}$ data confirm that ammonia was more readily utilized than was nitrate.
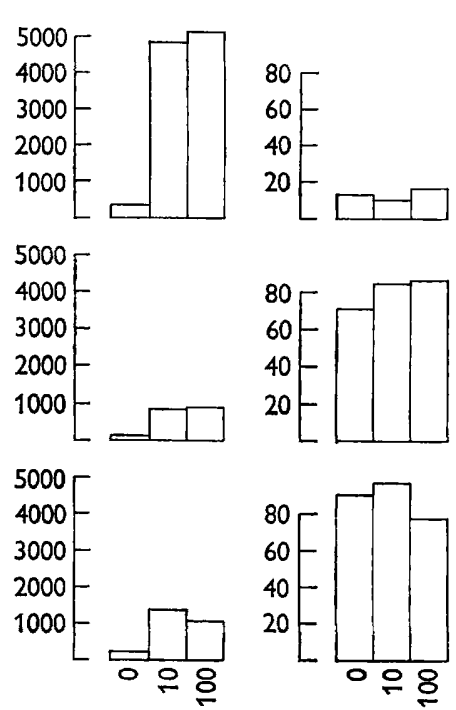

Fig. 1
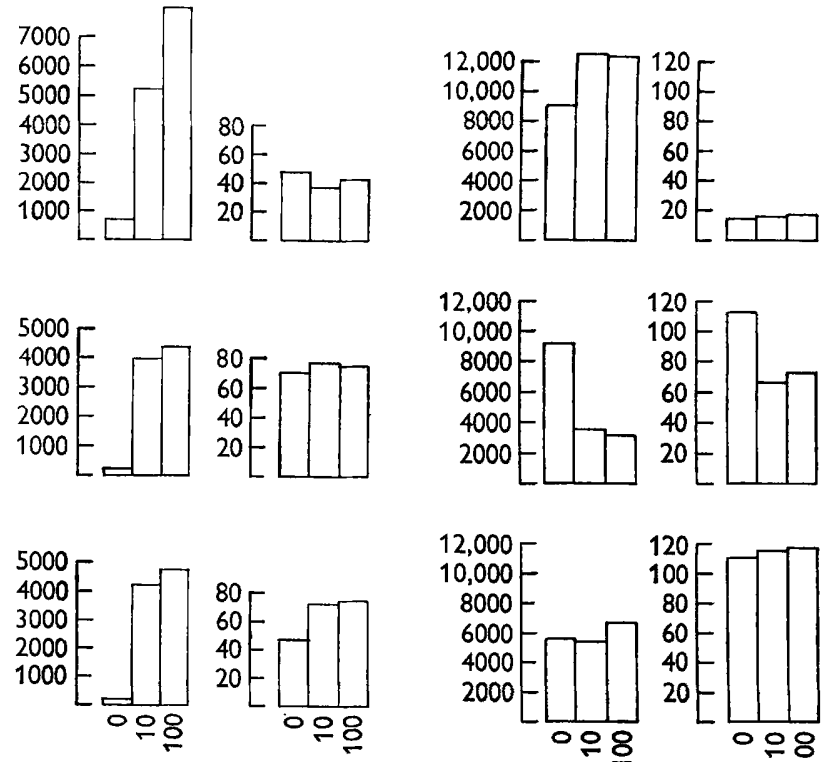

Fig. 2

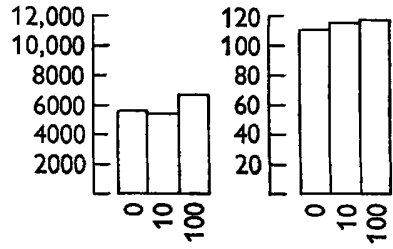

Fig. 3

Fig. 1. The effect of oxygen pressure and molybdenum content of the culture medium on nitrate reductase activity and total bacterial-N of Photobacterium sepia grown with $\mathrm{NH}_{4} \mathrm{Cl}(6.5 \mathrm{~g} . / 1$.$) . Ordinate left: specific activity of nitrate reductase ( \mu \mathrm{m}-\mathrm{mole}$ $\mathrm{NO}_{2}-/ 10 \mathrm{~min}$./mg. bacterial-N). Ordinate right: $\mathrm{mg}$. bacterial-N/400 ml. culture. Abscissae : 0, 10, $100 \mu \mathrm{g}$. Mo/l. culture medium. Top: $1 \%(\mathrm{v} / \mathrm{v}) \mathrm{O}_{2}$ in $\mathrm{N}_{2} ;$ middle: $10 \%$ $(\mathrm{v} / \mathrm{v}) \mathrm{O}_{2}$ in $\mathrm{N}_{2} ;$ bottom: $20 \%(\mathrm{v} / \mathrm{v}) \mathrm{O}_{2}$ in $\mathrm{N}_{2}$.

Fig. 2. The effect of oxygen pressure and molybdenum content of the culture medium on nitrate reductase activity and total bacterial-N of Photobacterium sepia grown with $\mathrm{KNO}_{3}(12.2 \mathrm{~g} . / \mathrm{l}$.$) . Ordinate left: specific activity of nitrate reductase ( \mu \mathrm{m}$-mole $\mathrm{NO}_{2}-10 \mathrm{~min} . / \mathrm{mg}$. bacterial-N). Ordinate right: $\mathrm{mg}$. bacterial-N/400 ml. culture. Abscissae : 0, 10, $100 \mu \mathrm{g}$. Mo/l. culture medium. Top: $1 \%(\mathrm{v} / \mathrm{v}) \mathrm{O}_{2}$ in $\mathrm{N}_{2} ;$ middle: $10 \%$ $(\mathrm{v} / \mathrm{v}) \mathrm{O}_{2}$ in $\mathrm{N}_{2} ;$ bottom: $20 \%(\mathrm{v} / \mathrm{v}) \mathrm{O}_{2}$ in $\mathrm{N}_{2}$.

Fig. 3. The effect of oxygen pressure and molybdenum content of the culture medium on nitrate reductase activity and bacterial-N of Photobacterium sepia grown with $\mathrm{NH}_{4} \mathrm{NO}_{3}(5 \mathrm{~g} . / 1$.$) . Ordinate left: specific activity of nitrate reductase ( \mu \mathrm{m}$-mole $\mathrm{NO}_{2}-/ 10 \mathrm{~min} . / \mathrm{mg}$. bacterial-N). Ordinate right: $\mathrm{mg}$. bacterial-N/400 ml. culture. Abscissae : 0, 10, $100 \mu \mathrm{g}$. Mo/l. culture medium. Top: $1 \%(\mathrm{v} / \mathrm{v}) \mathrm{O}_{2}$ in $\mathrm{N}_{2} ;$ middle: $10 \%$ $(\mathrm{v} / \mathrm{v}) \mathrm{O}_{2}$ in $\mathrm{N}_{2} ;$ bottom: $20 \%(\mathrm{v} / \mathrm{v}) \mathrm{O}_{2}$ in $\mathrm{N}_{2}$. 
Aeration of cultures and effects of trace metals. The effects of nitrogen source $\left(\mathrm{NH}_{4} \mathrm{Cl}, \mathrm{KNO}_{3}, \mathrm{NH}_{4} \mathrm{NO}_{3}\right)$, oxygen supply (0, 10 and $20 \%, \mathrm{v} / \mathrm{v}, \mathrm{O}_{2}$ in $\left.\mathrm{N}_{2}\right)$ and molybdenum content $(0,10,100 \mu \mathrm{g} . / \mathrm{l}$.$) of the culture medium on the nitrate$ reductase activity of the organisms are illustrated in Figs. 1, 2, 3. Molybdenum was required for nitrate reductase activity when the nitrogen source was either $\mathrm{NH}_{4} \mathrm{Cl}$ or $\mathrm{KNO}_{3}$ irrespective of the gas mixture used. At $20 \%(\mathrm{v} / \mathrm{v}) \mathrm{O}_{2}$ level, molybdenum deficiency restricted growth when $\mathrm{KNO}_{3}$ was sole nitrogen source, but was without effect when $\mathrm{NH}_{4} \mathrm{Cl}$ or $\mathrm{NH}_{4} \mathrm{NO}_{3}$ were used. Total yields of organism were markedly decreased at $1 \%(\mathrm{v} / \mathrm{v}) \mathrm{O}_{2}$ when the organism was grown with any of the nitrogen compounds tested.

Table 3. Nitrate reductase activity and NO uptake of Photobacterium sepia in relation to the molybdenum content of the culture medium

$\mathrm{NH}_{4} \mathrm{NO}_{3}$ was the nitrogen source; $10 \%(\mathrm{v} / \mathrm{v}) \mathrm{O}_{2}$ in $\mathrm{N}_{2}$ was sparged through the medium.

Mo content

Nitrate reductase specific activity

( $\mu$ g./l. medium) ( $\mu \mathrm{m}$-mole $\mathrm{NO}_{2}{ }^{-}$formed $/ 10 \mathrm{~min} . / \mathrm{mg}$. bacterial-N)

NO uptak
$\mu \mathrm{l}$. NO/hr/mg.
$20 \cdot 4$
$16 \cdot 6$
$11 \cdot 9$
$10 \cdot 9$
$12 \cdot 8$

The amount of constitutive nitrate reductase formed with $\mathrm{NH}_{4} \mathrm{Cl}$ was markedly decreased by increasing the $\mathrm{O}_{2}$ pressure in the medium (Fig. 1).

An unusual effect of molybdenum $(10,100 \mu \mathrm{g}$. Mo/l.) in depressing nitrate reductase activity and yield of organism was observed in the $\mathrm{NH}_{4} \mathbf{N O}_{3}$ cultures (Fig. 3). This occurred only when $10 \%(\mathrm{v} / \mathrm{v}) \mathrm{O}_{2}$ was sparged through the cultures. Both nitrate reductase activity and the uptake of nitric oxide were depressed by increasing the Mo content of the culture media from 2 to $20 \mu \mathrm{g}$./1. (Table 3). These toxic effects, however, became less pronounced after repeated subculturing in Modeficient medium (Table 4). At the 13th subculture the effects were reversed, since then a deficiency of Mo depressed nitrate reductase activity. The toxic effects did not occur with media which contained $\mathrm{KNO}_{3}$ or $\mathrm{NH}_{4} \mathrm{Cl}$.

Table 4. The effect of transferring Photobacterium sepia through several subcultures of medium deficient in molybdenum on the nitrate reductase activity of the organisms

$\mathrm{NH}_{4} \mathrm{NO}_{3}$ was the nitrogen source; cultures were aerated with $10 \%(\mathrm{v} / \mathrm{v}) \mathrm{O}_{2}$ in $\mathrm{N}_{2}$.

\begin{tabular}{|c|c|c|c|c|c|c|}
\hline \multirow[b]{3}{*}{$\begin{array}{c}\text { Mo content } \\
(\mu \mathrm{g} . / \mathrm{l} . \\
\text { medium })\end{array}$} & \multicolumn{6}{|c|}{ Number of transfers } \\
\hline & \multicolumn{2}{|c|}{2} & \multicolumn{2}{|c|}{12} & \multicolumn{2}{|c|}{13} \\
\hline & $\begin{array}{c}\text { Specific } \\
\text { activity* } \\
\text { of enzyme }\end{array}$ & $\begin{array}{c}\text { Bacterial-N } \\
\text { (mg.) }\end{array}$ & $\begin{array}{l}\text { Specific } \\
\text { activity } \\
\text { of enzyme }\end{array}$ & $\begin{array}{l}\text { Bacterial-N } \\
\text { (mg.) }\end{array}$ & $\begin{array}{l}\text { Specific } \\
\text { activity } \\
\text { of enzyme }\end{array}$ & $\begin{array}{l}\text { Bacterial-N } \\
\text { (mg.) }\end{array}$ \\
\hline 0 & 9100 & $22 \cdot 4$ & 7950 & 14.7 & 790 & $15 \cdot 3$ \\
\hline 10 & 3550 & $13 \cdot 2$ & 5600 & $10 \cdot 1$ & 3280 & $15 \cdot 3$ \\
\hline 100 & 3140 & 14.5 & 5360 & $10 \cdot 1$ & 3410 & $13 \cdot 1$ \\
\hline
\end{tabular}

* Specific activity of nitrate reductase $\mu \mathrm{m}-\mathrm{mole} \mathrm{NO}_{2}-$ formed $/ 10 \mathrm{~min} . / \mathrm{mg}$. bacterial-N. 
An inhibition of nitrate reductase activity in organisms grown with $\mathrm{NH}_{4} \mathrm{NO}_{3}$ was also observed with vanadium and tungsten (Table 5). Tungsten brought about a drastic decrease in enzyme activity. Although nitrate reductase was markedly decreased in amount, the yields of organism were unaffected, since the ammonium radical was being utilized.

Table 5. Effect of molybdenum, vanadium and tungsten on nitrate reductase activity in Photobacterium sepia $\mathrm{NH}_{4} \mathrm{NO}_{3}$ medium, second subculture, aeration with $10 \%(\mathrm{v} / \mathrm{v}) \mathrm{O}_{2}$ in $\mathrm{N}_{2}$. ( $\mu$ g. metal/l. medium) Nitrate reductase Bacterial-N

$\begin{array}{lrrr}\text { Control } & 0 & 1840 & \mathbf{2 2} \cdot 7 \\ \text { Mo (as molybdate) } & 10 & \mathbf{9 4 0} & \mathbf{2 6} \cdot 0 \\ \text { V (as vanadium oxychloride) } & 10 & \mathbf{7 9 5} & \mathbf{2 2 \cdot 8} \\ \text { W (as tungstate) } & 10 & \mathbf{1 7 3} & \mathbf{2 2 \cdot 0}\end{array}$

* Nitrate reductase specific activity $\mu \mathrm{m}$-mole $\mathrm{NO}_{2}-/ 10 \mathrm{~min} . / \mathrm{mg}$. bacterial-N.

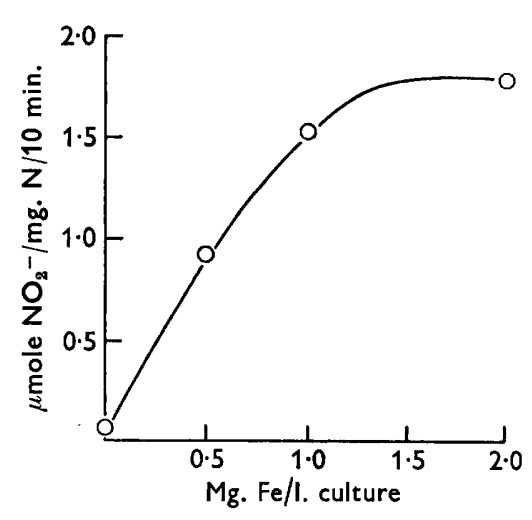

Fig. 4

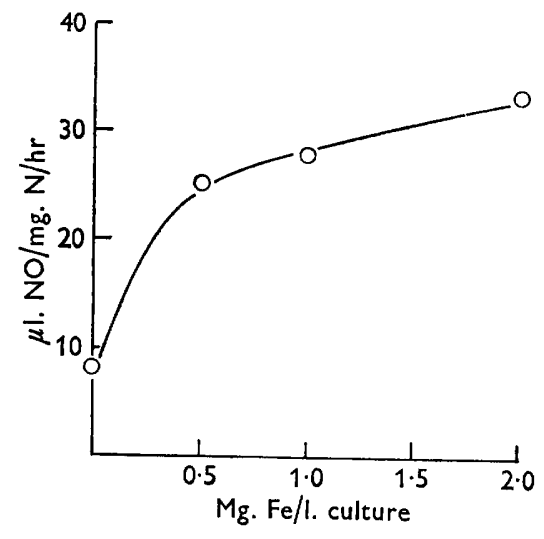

Fig. 5

Fig. 4. The effect of the iron content of the culture medium on nitrate reductase activity of Photobacterium sepia.

Fig. 5. The effect of the iron content of the culture medium on the uptake of nitric oxide by Photobacterium sepia.

Nitrate reductase activity and nitric oxide uptake were both dependent on an adequate supply of iron in the culture medium (Figs. 4, 5); about 1.5 mg. Fe/l. produced maximal activity for nitrate and nitric oxide reductases.

\section{Extraction of nitrate reductase}

The nitrate reductase activity in cell-free extracts of Photobacterium sepia grown in peptone medium with $\mathrm{KNO}_{3}$ or $\mathrm{NH}_{4} \mathrm{Cl}$, respectively was determined (Table 6). The enzyme appeared to be similar whether extracted from organisms grown with $\mathrm{KNO}_{3}$ or with $\mathrm{NH}_{4} \mathrm{Cl}$; in both cases the second water-extract contained most of the activity, and when the extracts were adjusted to $\mathrm{pH} 4.5$ with acetic acid the enzyme was similarly distributed between the precipitate and the supernatant fractions. The extracts from organisms grown with $\mathrm{KNO}_{3}$ had significantly higher 


\section{D. J. D. Nicholas, W. J. Redmond and M. A. Wright}

activities than did whole organisms. The amount of enzyme in whole organisms from these cultures increased markedly after storage overnight at $4^{\circ}$, e.g. from a specific activity of $\mathbf{5 5 5}$ to one of $\mathbf{2 5 1 0}$. This suggests that an inhibitor of the enzyme was present in the freshly collected organisms.

Table 6. The extraction of nitrate reductase from Photobacterium sepia grown in peptone medium with $\mathrm{KNO}_{3}$ or $\mathrm{NH}_{4} \mathrm{Cl}$

\begin{tabular}{|c|c|c|c|c|c|}
\hline \multirow[b]{2}{*}{$\begin{array}{l}\text { Nitrogen } \\
\text { source }\end{array}$} & \multicolumn{5}{|c|}{ Preparation } \\
\hline & $\begin{array}{c}\text { Intact } \\
\text { organisms }\end{array}$ & $\begin{array}{c}\text { 1st water } \\
\text { extract }\end{array}$ & $\begin{array}{l}\text { 2nd water } \\
\text { extract }\end{array}$ & $\begin{array}{c}\text { Precipitate* } \\
\text { obtained at } \\
\text { pH } 4.5\end{array}$ & $\begin{array}{c}\text { Supernatant } \\
\text { liquid at } \\
\text { pH 4.5 }\end{array}$ \\
\hline & \multicolumn{5}{|c|}{ Nitrate reductase specific activity $\dagger$} \\
\hline $\begin{array}{l}\mathrm{KNO}_{3} \\
\mathrm{NH}_{4} \mathrm{Cl}\end{array}$ & $\begin{array}{r}380 \\
4590\end{array}$ & $\begin{array}{l}410 \\
340\end{array}$ & $\begin{array}{l}1880 \\
2540\end{array}$ & $\begin{array}{l}292 \\
417\end{array}$ & $\begin{array}{l}740 \\
400\end{array}$ \\
\hline
\end{tabular}

* Water extract adjusted to $\mathrm{pH} 4.5$ by adding M-acetic acid and centrifuged for $10 \mathrm{~min}$. at $25,000 \mathrm{~g}$ at $4^{\circ}$; precipitate taken up in $0.05 \mathrm{M}$-phosphate buffer (pH 6.5).

$\dagger$ Nitrate reductase specific activity: $\mu \mathrm{m}$-mole $\mathrm{NO}_{2}-10 \mathrm{~min}$. $/ \mathrm{mg}$. bacterial-N.

\section{DISCUSSION}

Contrary to a previous report, the halophylic bacterium Photobacterium sepia (previously assumed to be Achromobacter fischeri by Sadana \& McElroy, 1957) grows with nitrate as sole nitrogen source. Since it requires molybdenum and iron for growth and for its nitrate reductase activity and since the amount of enzyme was decreased at high oxygen pressures, it resembles the dissimilatory nitrate reductase systems found in other bacteria and fungi (Verhoeven, 1952; Sato, 1956; Fewson \& Nicholas, 1961; Walker \& Nicholas, 1961; Nicholas, 1961, 1963).

It is of interest that nitrate reductase in Photobacterium sepia (Achromobacter fischeri) is constitutive; it is formed in this organism with ammonium chloride and without nitrate, its substrate. In other micro-organisms, nitrate or nitrite is required in the medium to produce nitrate reductase activity in the cells. The role of this constitutive enzyme in the organism grown with ammonium chloride is not clear, since under these conditions it has neither an assimilatory nor a dissimilatory function. Ammonia does not depress the formation of nitrate reductase in $\boldsymbol{P}$. sepia as it does in Neurospora, where a 'feed back repression' mechanism functions presumably as a physiological control for nitrate utilization in vivo (Kinsky, 1961).

Pichinoty \& d'Ornano $(1961 a, b)$ showed that the induction of nitrate reductase in Aerobacter aerogenes by nitrate was associated with a de novo synthesis of this enzyme from free amino acids and that this process was greatly inhibited in aerobic cultures. They established that oxygen reversibly inhibited the biosynthesis of nitrate reductase. A similar inhibitory effect of oxygen on the production of this enzyme has now been observed in Photobacterium sepia grown with either nitrate or ammonia.

The unusual inhibitory effect of molybdenum on growth and on nitrate reductase activity in Photobacterium sepia grown with $\mathrm{NH}_{4} \mathrm{NO}_{3}$ at $10 \%(\mathrm{v} / \mathrm{v}) \mathrm{O}_{2}$ and the annullment of this effect after 13 subcultures, is difficult to explain. At first sight it might seem that the toxic effect of molybdenum is on the uptake of the ammonium radical, since ${ }^{15} \mathrm{~N}$ experiments showed that about seven times as much nitrogen was 
derived from that source. This, however, is not borne out by the fact that no toxic effects from molybdenum were observed in cells grown with ammonium chloride. Vanadium and especially tungsten had an effect like molybdenum. Tungstate was shown by Higgins, Richert \& Westerfeld (1956) to be a competitive inhibitor of nitrate reductase in Neurospora and Takahashi \& Nason (1957) obtained similar results with Azotobacter.

The uptake of nitric acid was depressed in Photobacterium sepia deficient in iron; similar results were obtained by Fewson \& Nicholas (1960) and in Pseudomonas fluorescens (unpublished results).

We are grateful to Miss Anne Morrison (National Collection Type Cultures), Torry Research Station, Aberdeen, for carrying out the biochemical tests that identified the organism used here as Photobacterium sepia and for establishing the purity of the cultures; to Mr D. J. Fisher for assistance with ${ }^{15} \mathrm{~N}$ experiments.

\section{REFERENCES}

Bergey's Manual of Determinative Bacteriology (1957). 7th ed. Ed. by R. S. Breed, E. G. D. Murray \& N. R. Smith. Baltimore: Williams and Wilkins Co.

Fewson, C. A. \& Nicholas, D. J. D. (1960). Utilisation of nitric oxide by micro-organisms and higher plants. Nature, Lond. 188, 794.

Fewson, C. A. \& Nicholas, D. J. D. (1961). Nitrate reductase from Pseudomonas aeruginosa. Biochim. biophys. Acta, 49, 335.

Higgins, E. S., Richert, D. A. \& Westerfeld, W. W. (1956). Tungstate antagonism of molybdate in Aspergillus niger. Proc. Soc. exp. Biol., N.Y. 92, 509-11.

KINSKY, S. C. (1961). Induction and repression of nitrate reductase in Neurospora crassa. J. Bact. 82, 989.

Lindeberg, G., Lode, A., \& Somme, R. (1963). Effect of oxygen on formation and activity of nitrate reductase in a halophilic Achromobacter species. Acta chem. scand. 17, 232.

Lowry, O. H., Rosebrough, N. J., Farr, A. L. \& Randall, R. J. (1951). Protein measurement with the Folin phenol reagent. J. biol. Chem. 193, 265.

Medina, A. \& Nicholas, D. J. D. (1957). Interference by reduced pyridine nucleotides in the diazotization of nitrite. Biochim. biophys. Acta, 23, 440.

Nicholas, D. J. D. (1952). The use of fungi for determining trace metals in biological materials. Analyst, Lond. 77, 629.

Nicholas, D. J. D. \& Medina, A. (1960). A nitrate reductase from Neurospora crassa. Biochim. biophys. Acta, 37, 468.

Nicholas, D. J. D. \& Nason, A. (1954). Mechanism of action of nitrate reductase from Neurospora. J. biol. Chem. 211, 183.

Nicholas, D. J. D. (1961). Minor mineral nutrients. A. Rev. Pl. Physiol. 12, 63.

Nicholas, D. J. D. (1963). The metabolism of inorganic nitrogen and its compounds in micro-organisms. Biol. Rev. 38, 530.

Nicholas, D. J. D., Redmond, W. J. \& Wright, M. A. (1963). Molybdenum and iron requirements for nitrate reductase in Photobacterium sepia. Nature, Lond. 200, 1125.

Pichinoty, F. \& D'Ornano, L. (1961 $a)$. Influence des conditions de culture sur la formation de la nitrate reductase d'Aerobacter aerogenes. Biochim. biophys. Acta, 48, 218.

Pichinoty, F. \& D'Ornano, L. (1961 $b$ ). Inhibition by oxygen of biosynthesis and activity of nitrate reductase in Aerobacter aerogenes. Nature, Lond. 191, 879.

Sadana, J. C. \& McElroy, W. D. (1957). Nitrate reductase from Achromobacter fischeri. Purification and properties: Function of flavines and cytochrome. Archs. Biochem. 67, 16.

San Pietro, A. (1957). The measurement of stable isotopes. Meth. Enzymol. 4, 473. 


\section{D. J. D. Nicholas, W. J. Redmond and M. A. Wright}

SATo, R. (1956). The cytochrome system and microbial reduction of nitrate. In Inorganic Nitrogen Metabolism. Ed. by W. D. McElroy \& B. Glass, p. 163. Baltimore: The Johns Hopkins Press.

Simms, P. \& Cocking, C. (1958). Assay of isotopic nitrogen by mass-spectrometer. Nature, Lond. 181, 474.

SPEnCER, R. (1955). Taxonomy of certain luminous bacteria. J. gen. Microbiol. 13, 111.

SteINBERG, R. A. (1935). Nutrient solution purification for removal of heavy metals in deficiency investigations with Aspergillus niger. J. agric. Res. 51, 413.

Takahashi, H. \& Nason, A. (1957). Tungstate as a competitive inhibitor of molybdate in nitrate assimilation and in $\mathrm{N}_{2}$ fixation by Azotobacter. Biochim. biophys. Acta, 23, 433.

VerHoEven, W. (1952). Aerobic sporeforming nitrate reducing bacteria. Thesis. University of Delft.

Walker, G. C. \& Nicholas, D. J. D. (1961). An iron requirement for a dissimilatory nitrate reductase in Neurospora crassa. Nature, Lond. 189, 141. 